\title{
A Model of Factors Affecting theUse of Personal Protective Equipment Using a Path Analysis among PLTU Contractor Workers in East Java
}

\author{
Model Faktor Penggunaan Alat Pelindung Diri dengan Path Analysis pada \\ Pekerja Kontraktor PLTU di Jawa Timur
}

\author{
Wisdha Riezqi Ginandhani, Dewi Kurniasih, Farizi Rachman \\ Program Study of Occupational Safety and Health Engineering \\ Departement of Marine Engineering, Shipbuilding Institute of Polytechnic Surabaya \\ Chemical Engineering ITS, Sukolilo, Surabaya, 60111 Indonesia
}

\begin{abstract}
Introduction: Based on the survey data in one of the PLTUs in East Java from January-November 2019, there were 9.134 findings of non-compliance with PPE. In addition, based on the audit data from October to November 2019, there were 125 findings of non-compliance with the use of PPE. The factors causing this non-compliance could be seen from the characteristics of the workers or could be based on the Health Belief Model (HBM) approach through 6 constructs. Based on these data, this article aimsto analyze a model of factors that have a direct and indirect effect on the use of PPE on PLTU contractor workers in East Java. The researchers used the Health Belief Model approach because the use of PPE for workers is an effort related to healthy behavior in the workplace. Methods: This research was a quantitative research. The total sample was 100 workers from a population of 400 contractors workers, based on the Slovin methodand as a fulfillment of the path analysis requirement. The analyses of direct and indirect effects between variables used a path analysis method. Results: The results of data processing showa direct effect of perceived benefits( $t=4,837)$, cues to action $(\mathrm{t}=5,990)$, perceived severity $(\mathrm{t}=2,131)$, knowledge $(\mathrm{t}=3,183)$, and perceived susceptibility $(\mathrm{t}=2,212)$ on the use of PPE, while education iis known to have an indirect effect on the use of PPE through knowledge( $t=2$,222). Conclusion: Perceived benefits, cues to action, perceived severity, knowledge, and perceived susceptibility have a direct effect on the use of PPE. However, education has an indirect effect on the use of PPE through knowledge.
\end{abstract}

Keywords: health belief model, occupational diseases, path analysis, personal protective equipment

\section{ABSTRAK}

Pendahuluan: Pada salah satu PLTU di Jawa Timur, data survey mulai Januari hingga November 2019 ada 9.134 temuan ketidakpatuhan penggunaan APD. Selain itu, data audit kontraktor pada Oktober dan November 2019, terdapat 125 temuan ketidakpatuhan penggunaan APD. Faktor penyebab ketidakpatuhan ini dapat dilihat dari karakteristik pekerja atau berdasarkan pendekatan HBM melalui 6 konstruk. Berdasarkan data tersebut, artikel ini bertujuan untuk menganalisis model faktor yang berpengaruh secara langsung dan tidak langsung terhadap pengunaan APD pada pekerja kontraktor PLTU di Jawa Timur. Untuk menjelaskannya, peneliti menggunakan pendekatan Health Belief Model, karena penggunaan APD bagi pekerja merupakan upaya yang berkaitan dengan perilaku sehat di tempat kerja. Metode: Penelitian ini bersifat kuantitatif. Sample penelitian berjumlah 100 pekerja dari populasi 400 pekerja kontraktor, sesuai dengan metode Slovin dan memenuhi persyaratan path analysis. Analisis pengaruh secara langsung dan tidak langsung tiap variabel dengan menggunakan metode path analysis. Hasil: Hasil pengolahan data menunjukkan adanya pengaruh langsung perceived benefits (thitung=4,837), cues to action (thitung=5,990), perceived severity (thitung=2,131), pengetahuan (thitung=3,183), dan perceived susceptibility (thitung=2,212) terhadap penggunaan APD, sedangkan pendidikan memiliki pengaruh tidak langsung terhadap penggunaan APD melalui pengetahuan (thitung=2,222). Simpulan: Perceived benefits, cues to action, perceived severity, pengetahuan, perceived susceptibility memiliki pengaruh langsung terhadap penggunaan APD. Pendidikan memiliki pengaruh tidak langsung terhadap penggunan APD melalui pengetahuan

Kata kunci: alat pelindung diri, health belief model, penyakita akibat kerja, path analysis

Corresponding Author:

Wisdha Riezqi Ginandhani

Email: wisdhariezqiginandhani@gmail.com

Telephone: +6289635692666

Dewi Kurniasih

Email: dewi.kurniasih@ppns.ac.id

Telephone: +628129217043

C2021 IJOSH All right reserved. Open access under CC BY NC-SA license doi: 10.20473/ijosh.v10i1.2021.137-143 Received August 07, 2020, received in revised form March 05, 2021, Accepted March 05, 2021, Published: April 2021 


\section{INTRODUCTION}

Electrical energy is needed to facilitate the fulfillment of human needs. Efforts to produce electrical energy must go through a long process with complicated equipment and technology. One of the power plants is the steam power plant. The steam powerplant is an industry with a high risk of hazards, such as working at a high place, welding, grinding, ergonomics, mechanics, limited space, and other hazards, which can potentially cause accidents and occupational diseases. Therefore, efforts to anticipate the risk of high hazards are required for occupational safety and health.

Basically, there are many sources of causes of accidents and occupational diseases, one of which is unsafe acts. According to Henrich in Suma'mur (2013), 88\% of unsafe acts contribute to the accidents or occupational diseases, $10 \%$ were caused by unsafe conditions, and $2 \%$ were caused by unavoidable conditions (things that could not be avoided). In addition, based on the data from one steam power plant in East Java from the beginning of 2013 to 2018 , there was a significant increase in the number of unsafe acts, and it could trigger accidents or occupational diseases. This is in accordance with Afini, Koesyanto and Budiono (2012) their research, stating that accidents that occurr in the installation unit are caused by several factors, namely not noncompliance with the use of PPE when the accident occurs, poor characteristics of the subjects, absence from OHS trainings, and the hot temperature of the room which causes uncomfortable feeling to work. Thus, non-compliance with the iuse iof ipersonal iprotective iequipment (iPPE) iis ione iof ithe unsafe acts ithat ican exacerbate ithe detrimental impacts if an accident occurs.

Based on data fromone of the steam power plants in East Java from the beginning of 2019 to November 2019, there were 9.134 cases of noncompliance with the use of PPE. In addition, based on the audit data, one of the steam power plants in East Java in October and November, there were 125 cases of non-compliance with the use of PPE. Based on these data, this article aims to analyze a model of factors that affect directly and indirectly to the use of PPE among steam power plant contractor workers in East Java. Furthermore, in explaining the model of factors that affect the use of PPE, the researcher used the Health Belief Model (HBM) approach because the use of PPE for workers is an effort related to healthy behavior in the workplace.
This approach is in accordance with Corner's opinion cited in Fanani and Dewi (2014) stating that this theory is a model of individual trust in determining whether or not to behave in healthy behavior. Research conducted by Wright et al. (2019) concerning PPE compliance states that HBM is a theoretical framework that is useful for research regarding PPE compliance because the construct of this concept is able to explain and predict certain behaviors and attitudes that affect the use of PPE. From the definitions described above, it could be concluded that Health Belief Model is a theoretical model of health beliefs which describes individual considerations before behaving healthily, in the form of the determination of attitude to do or not to do activities related to health. This theory has 6 constructs of perception, which could be used to explain health behavior in the use of PPE. The constructs include: (1) perceived severity, which is workers' perception of the adverse consequences of exposure to occupational diseases; (2) perceived susceptibility, which is workers' perception about the risk of being exposed to occupational diseases or about how workers' behavior could minimize occupational diseases; (3) perceived benefits, which are the motives of workers to conduct behavioral use of PPE based on the value/usefulness in reducing the risk of occupational diseases; (4) cues to action, which are an internal stimulus ior iexternal istimulus ithat iinfluences the idesire of workers ito iuse iPPE; (5) perceived barriers, which are an individual's belief in evaluating the obstacles encountered in adopting a behavior; and (6)self-efficacy, which isa belief about the ability possessed by the individual about whether or not he could or could not make changes in behavior (Dewi, Rahardjo and Murti, 2019).

In connection with the concept of HBM, the researchers limit the analysis of a model of factors that affect the use of PPE based on 4 constructs, namely: iperceived iseverity, iperceived ibenefits, iperceived susceptibility, and cues to action, so that the research results can be used to improve workers' compliance in using PPE in the workplace which has high potential hazards.

\section{METHODS}

This quantitative research was conducted on 400 contractor workers in one of the steam power plants in East Java in May 2020 with an ethics permit number $\mathrm{POMI} / \mathrm{KAP} / \mathrm{BJ} / 59672-85$, and 
used a path analysis method. From this population, the determination of the number of samples was calculated based on the Slovin formula with a margin of error of $10 \%$, so the total number of samples was 80 respondents. The sampling technique used was a simple random sampling. Moreover, the analysis of the data using the path analysis method required a minimum of 100 respondents, so the researcher added 20 respondents to complete the required sample size.

In this study, the exogenous variables were education, perceived benefits, and cues to action. The intervening variables were knowledge, perceived severity, and perceived susceptibility. Meanwhile, the endogenous variable was the use of PPE. For the data collection in this study, the primary data were obtained from questionnaires, and the secondary data were obtained from the company's data on the number of contractor workers, on the non-compliance with the use of PPE, on the cases of unsafe acts, and on the audit about the non-compliance with the use of PPE. All data from the questionnaires were then processed and analyzed using the path analysis method in the AMOS program.

\section{RESULTS}

The characteristics of the respondents from the results of the questionnaires are shown in Table 1.

Based on the information obtained in Table 1, the respondents in one of the steam power plants in East Java are mostly over 30 years old (63\%), have working experience less than 10 years $(80 \%)$, and have a senior high school education level or lower $(66 \%)$.

The results of data processing using the path analysis method are shown in Figure 1. Figure 1 shows that the effect of perceived severity on the use of PPE is 0.12 , knowledge on the use of PPE is 0.19 , perceived susceptibility on the use of PPE is $0.12-$, perceived benefits on the use of PPE is 0.34 , cues to action on the use of PPE is 0.40 , and education on knowledge is 0.28 .

Based on Table 2, all path coefficients are significant. It could also be seen that the P-value fulfills the requirements (P-value $\leq 0.05$ ).

Based on Table 3, the Tvalue of the direct effect of perceived benefits on the use of PPE is 4.837. The Tvalue of the direct effect of cues to action on the use of PPE has the highest effect value, which is 5.990. The Tvalue of the direct effect of perceived severity on the use of PPE is 2.131. The Tvalue of the direct effect of knowledge on the use of PPE is 3.183. iThe Tvalue of the direct effect of perceived susceptibility on the use of PPE is 2.212. The Tvalue of the indirect effect of education on the use of PPE through knowledge is 2.222 .

Based on Table 4, the value of the direct effect of perceived benefits on the use of PPE is 0.362 ; it means that the direct effect of perceived benefits on the use of PPE is $36.2 \%$. The value of the direct effect of cues to action on the use of PPE has the highest effect value, which is 0.449 ; it means that

Table 1. Characteristics of Respondents in the Steam Power Plant, May 2020

\begin{tabular}{llcc}
\hline Characteristic & Category & Frequency & Percentage \\
\hline \multirow{2}{*}{ Age } & $\leq 30$ years & 37 & $37 \%$ \\
& $>30$ years & 63 & $63 \%$ \\
W o r k i n g & $\leq 10$ years & 80 & $80 \%$ \\
experience & $>10$ years & 20 & $20 \%$ \\
Education & $\leq$ SHS & 66 & $66 \%$ \\
& $>$ SHS & 34 & $34 \%$ \\
\hline
\end{tabular}

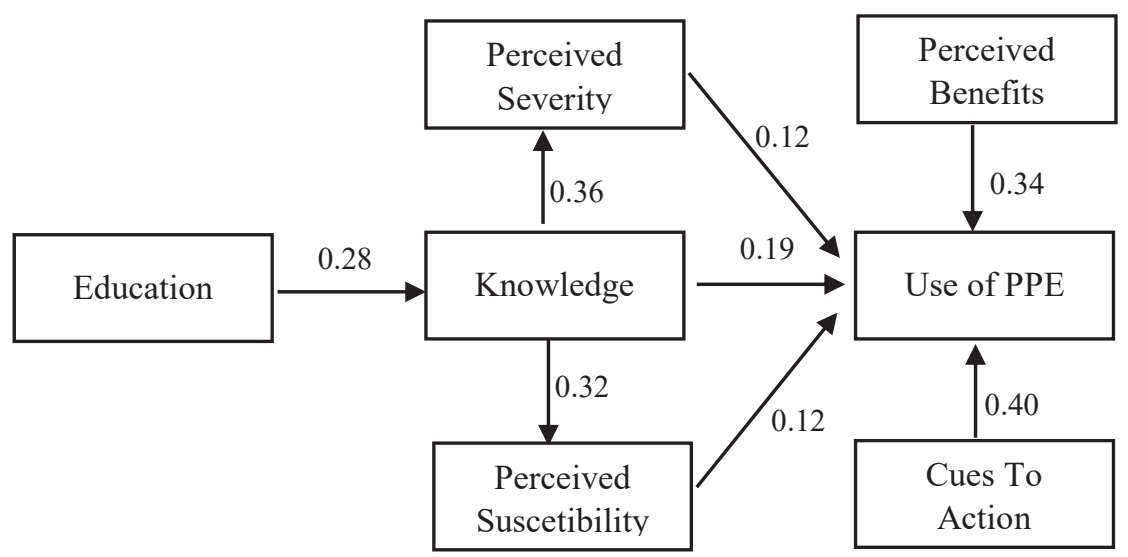

Figure 1. A Model of factors that Affect the use of PPE 
Table 2. Outputs of Regression Weights Between Variables

\begin{tabular}{llcccc}
\hline & & Estimate & S.E. & C.R. & P \\
\cline { 3 - 6 } Knowledge & $\leftarrow$ Education & 0.285 & 0.084 & 3.394 & $* * *$ \\
Perceived severity & $\leftarrow$ Knowledge & 0.360 & 0.096 & 3.772 & $* * *$ \\
Perceived susceptibility & $\leftarrow$ Knowledge & 0.318 & 0.100 & 3.167 & 0.002 \\
Use of PPE & $\leftarrow$ Perceived severity & 0.118 & 0.055 & 2.131 & 0.033 \\
Use of PPE & $\leftarrow$ Knowledge & 0.187 & 0.059 & 3.183 & 0.001 \\
Use of PPE & $\leftarrow$ Perceived susceptibility & 0.117 & 0.053 & 2.212 & 0.027 \\
Use of PPE & $\leftarrow$ Perceived benefits & 0.339 & 0.070 & 4.837 & $* * *$ \\
Use of PPE & $\leftarrow$ Cues to action & 0.396 & 0.066 & 5.990 & $* * *$ \\
\hline
\end{tabular}

Table 3. Results of Path Analysis

\begin{tabular}{lccc}
\hline \multicolumn{1}{c}{ Variable X } & Variable $\mathbf{Z}$ & Variable $\mathbf{Y}$ & T-value \\
\hline $\begin{array}{l}\text { P e r c e i v e d } \\
\text { benefits }\end{array}$ & - & & 4.837 \\
$\begin{array}{l}\text { Cues to action } \\
\text { P e r c e i v e d }\end{array}$ & - & & 5.990 \\
$\begin{array}{l}\text { severity } \\
\text { Knowledge }\end{array}$ & - & Use of PPE & 2.131 \\
$\begin{array}{l}\text { P e r c e i v e d } \\
\text { susceptibility }\end{array}$ & - & & 3.183 \\
Education & Knowledge & & 2.212 \\
\hline
\end{tabular}

the effect iof cues to action on the use of PPE is $44.9 \%$. In contrast, the value of the direct effect of perceived severity on the use of PPE has the lowest effect value, which is 0.128 ; it means that the effect of perceived severity on the use of PPE is $12.8 \%$. Meanwhile, the value of the direct effect of knowledge on the use of PPE is 0.200 ; it means that the effect of knowledge on the use of PPE is $20.0 \%$. Moreover, the value of the direct effect of perceived susceptibility on the use of PPE is 0.130 ; it means that the effect of perceived susceptibility on the use of PPE is $13.0 \%$. On the other hand, the effect of education on the use of PPE through knowledge has an indirect effect with a value of 0.0638 ; it means that the effect of education on the use of PPE through knowledge is $6.38 \%$.

\section{DISCUSSION}

The results of path analysis test showthat there is a direct effect of perceived benefits on the use of PPE. This result is in line with previous research done by Dewi, Rahardjo, and Murti (2019) stating that a direct effect of perceived benefits on the implementation of PPE is statistically significant. Moreover, it isalso in accordance with
Table 4. Direct and Indirect Factors to the Use of PPE

\begin{tabular}{|c|c|c|c|c|}
\hline Variable $\mathrm{X}$ & Variable $\mathrm{Z}$ & $\begin{array}{c}\text { Variable } \\
\mathbf{Y}\end{array}$ & $\begin{array}{c}\text { Directly } \\
\text { Effect }\end{array}$ & $\begin{array}{c}\text { Indirectly } \\
\text { Effect }\end{array}$ \\
\hline $\begin{array}{c}\text { Perceived } \\
\text { benefits }\end{array}$ & - & $\begin{array}{l}\text { Use of } \\
\text { PPE }\end{array}$ & 0.362 & \\
\hline $\begin{array}{l}\text { Cues to } \\
\text { action }\end{array}$ & - & $\begin{array}{l}\text { Use of } \\
\text { PPE }\end{array}$ & 0.449 & \\
\hline $\begin{array}{l}\text { Perceived } \\
\text { severity }\end{array}$ & - & $\begin{array}{l}\text { Use of } \\
\text { PPE }\end{array}$ & 0.128 & \\
\hline Knowledge & - & $\begin{array}{l}\text { Use of } \\
\text { PPE }\end{array}$ & 0.200 & \\
\hline $\begin{array}{c}\text { Perceived } \\
\text { Susceptibility }\end{array}$ & - & $\begin{array}{l}\text { Use of } \\
\text { PPE }\end{array}$ & 0.130 & \\
\hline Education & Knowledge & $\begin{array}{l}\text { Use of } \\
\text { PPE }\end{array}$ & & 0.0638 \\
\hline
\end{tabular}

previous research done by Dewantara, Murti and Widyaningsih (2019) showing that perceived benefits are positively related to the use of PPE. If workers have high perceived benefits about the use of PPE, the workers would endeavor to avert work accidents and occupational diseases by using PPE. Perceived benefits are the motives of workers to conduct behavioral use of PPE based on its value/usefulness in reducing the risk of occupational diseases. This positive perception would determine a person in making decisions to behave healthily by using PPE in the workplace. However, thisresultis different from previous research done by Sakinah (2017) suggesting that there is no relation between perceived benefits and the use of PPE. Generally, individuals have sufficient perceived benefits, but in the implementation, these individuals tend not to behave well in the use of PPE.

Moreover, the results of path analysis test show that there iis a direct effect of cues to action on the use of PPE. This result is the same as previous research conducted by Dewi, Rahardjo, and Murti (2019) stating that there is a statistically significant relation 
between a direct and positive effect of cues to action on the implementation of PPE. The finding is also similar to previous research conducted by Sim, Moey and Tan (2014) suggesting that a significant predictor on the use of PPE is cues to action. If workers have high cues to action on the use of PPE, these workers would try to avoid work accidents and occupational diseases by using PPE. Cues to action are a stimulus that could increase one's motivation to make changes in behavior, and the stimulation could come from internal or external factors. This stimulation could affect workers' willingness to use PPE. According to Sakinah (2017), cues to action have a strong relationship with the motivation of individuals to use PPE.

The results of path analysis test also show that there is a direct effect of perceived severity on the use of PPE. This result is the same as previous research conducted by Rezaei, Seidi and Karbasioun (2019) stating that there is a significant and positive impact on workers in perceived severity to use PPE. Furthermore, it is also supported by previous research of Sim, Moey, and Tan (2014) stating that perceived severity is a significant predictor on the use of PPE. Workers who have a high perception of the severity of negative exposure have high willingness to use PPE during work. Perceived severity is the perception of the bad consequences of exposure to hazards that could cause occupational diseases in workers. In addition, the result of this research is also the same as previous research conducted by Dewi, Rahardjo, and Murti (2019) stating that there is a positive and direct effect of perceived severity on the use of PPE to prevent occupational diseases. It is because workers do not want to get serious occupational diseases, so workers try to prevent occupational diseases by using PPE.

The results of path analysis test also show that there is a direct effect of knowledge on the use of PPE. This result is the same as previous research conducted by Gunawan and Mudayana (2016) stating that knowledge and the use of PPE in workers have a significant relation. Chotimah, Haryadi, and Roestijawati (2019) in their research further state that knowledge has a significant effect on the use of PPE. However, this is different from the result of research conducted by Hidayah, Tunggul $P$ and Budi $\mathrm{R}$ (2015) arguing that knowledge and compliance with the use of PPE have no significant relation. Someone who has low knowledge tend to behave poorly, especially in keeping health and safety at work. Otherwise, someone with high knowledge tends to behave well in keeping personal health and safety at work. According to Kalasuat et al. (2019), knowledge is a process that occurs after a person makes an observation on a particular object through the senses, so there is a thorough understanding about an object. Knowledge is very important in shaping someone's action. Knowledge gives someone confidence to behave or not to behave. According to Jatmiko, Setiyawan and Atmojo (2017), compliant behavior in the use of PPE could be affected by several factors, including knowledge about PPE, PPE trainings, and supervision.

In addition, the results of path analysis test show that there is a direct effect of perceived susceptibility on the use of PPE. This result is in line with previous research conducted by Dewi, Rahardjo, and Murti (2019) suggesting that there is a direct and positive effect between perceived susceptibility and the use of PPE. Workerswho have a high perception of perceived susceptibility to work hazards and occupational diseases makeefforts to avert work hazards and occupational diseases by using PPE. Perceived susceptibility here refers to the extent to which a person believes that he is at a risk of contracting or being exposed to occupational diseases. This study is also supported by Rezaei, Seidi and Karbasioun (2019) that there is a significant and positive impact of perceived susceptibility on the use of PPE.

Interestingly, the results of path analysis show that there is an indirect effect of education on the use of PPE through knowledge. This study is in line with Sakinah's study (2017) that there is an indirect effect between education and the behavior of using PPE. It is also the same as research conducted by Putri (2017) suggesting that education with worker compliance in using PPE have a significant relation. However, it is different from previous research conducted by Arifin and Susanto (2013) showing that statistically, thereis no relationship between workers' education and compliance with the use of PPE. Harlan (2017) suggests that the higher education a person gets, the more likely it is for a person to obtain information or knowledge. Thus, it could be concluded that one of the factors that supports workers to have high knowledge and makes them obedient to usePPE is education.

\section{CONCLUSION}

Cues to action, perceived susceptibility, perceived benefits, knowledge, and perceived 
severity have a direct effect on the use of PPE. In addition, education has an indirect effect on the use of PPE through knowledge. Moreover, cues to action have the highest influence value in this study. So, it can be concluded thatthe efforts that need to be done by the steam power plant to handle the problem of non-compliance with the use of PPE on workers are by increasing the installation of safety signs in the workplace having the potential hazards for workers and by adding the installation of posters on the importance of using PPE for occupational safety and health.

\section{ACKNOWLEDGEMENTS}

The researchers would like to thank all parties who have helped the sustainability of this research; without the support from a PLTU in East Java, this research would not be accomplished. The researchers also thank Mrs. Dewi Kurniasih and Mr. Farizi Rachman for their guidance during this research, so this research could be completed in a timely manner.

\section{REFERENCES}

Afini, P. N., Koesyanto, H. and Budiono, I. (2012) 'Faktor Penyebab Kecelakaan Kerja di Unit Instalasi Pabrik Gula', Unnes Journal of Public Health., 1(1), pp. 45-50.

Arifin, A. B. and Susanto, A. (2013) 'FaktorFaktor yang Berhubungan dengan Kepatuhan Pekerja Dalam Pemakaian Alat Pelindung Diri (APD) di Bagian Coal Yard PT X Unit 3 \& 4 Kabupaten Jepara Tahun 2012', Jurnal Kesehatan Masyarakat, 2(1), pp. 1-6.

Chotimah, C. C., Haryadi and Roestijawati, N. (2019) 'Pengaruh Pengetahuan, Motivasi dan Persepsi Risiko terhadap Perilaku Penggunaan Alat Pelindung Diri Dasar yang Dimoderasi Faktor Pengawasan pada Civitas HospitaliaRSGMP Unsoed 1,2,3', Jurnal Ekonomi, Bisnis, dan Akuntansi, 21(3), pp. 1-11.

Dewantara, B. P., Murti, B. and Widyaningsih, V. (2019) 'Application of Health Belief Model and Social Cognitive Theory on the Use of Personal Protective Equipment among Workers at the Plywood Plant: Path Analysis Evidence from Lumajang, East Java', Journal of Health Promotion and Behavior, 4(4), pp. 306-318.
Dewi, R. D., Rahardjo, S. S. and Murti, B. (2019) 'Path Analysis on the Factors Affecting the Use of Personal Protection Equipment among Airport Construction Workers in Yogyakarta', Journal of Health Promotion and Behavior, 4(1), pp. 12-21.

Fanani, S. and Dewi, T. K. (2014) 'Health Belief Model pada Pasien Pengobatan Alternatif Supranatural dengan Bantuan Dukun', Jurnal Psikologi Klinis dan Kesehatan Mental, 3(4), pp. 54-59.

Gunawan, I. and Mudayana, A. A. (2016) 'Hubungan Antara Pengetahuan, Sikap Dan Motivasi Dengan Perilaku Penggunaan Alat Pelindung Diri Pada Pekerja Bagian Produksi PT.Katingan Indah Utama, Kabupaten Kotawaringin Timur, Provinsi Kalimantan Tengah', Unnes Journal of Public Health, 5(4), pp. 336-347.

Harlan, A. N. (2017) 'Faktor yang Berhubungan dengan Perilaku Penggunaan APD pada Petugas Laboratorium Rumah Sakit PHC Surabaya', The Indonesan Journal of Occupational Safety and Health, 6(3), pp. 278-287.

Hidayah, N., Tunggul P, E. and Budi R, B. (2015) 'Analisis Faktor yang Berhubungan dengan Kepatuhan Memakai Alat Pelindung Telinga pada Tenaga Kerja Bagian Produksi di PT. Total Dwi Daya Semarang Tahun 2014', Unnes Journal of Public Health, 4(1), pp. 1-7.

Jatmiko, F., Setiyawan, H. and Atmojo, T. B. (2017) 'Relationship Between Level Knowledge and Supervision To the Behavior of Apd Application in Construction Workers Pt Wika Beton Boyolali', Journal of Industrial Hygiene and Occupational Health, 2(1), p. 44.

Kalasuat, J. et al. (2019) 'Analysis of use of Protective Equipment (PPE) in Employees PT Conch Cement Manokwari District West Papua', Galore International Journal of Health Sciences and Research, 4(1), pp. 62-71.

Putri, K. D. S. (2017) 'Analisis Faktor yang Berhubungan dengan Kepatuhan Menggunakan Alat Pelindung Diri', The Indonesian Journal of Occupational Safety and Health, 6(3), pp. 311-320.

Rezaei, R., Seidi, M. and Karbasioun, M. (2019) 'Pesticide Exposure Reduction: Extending the Theory of Planned Behavior to Understand Iranian Farmers' Intention to Apply Personal Protective Equipment', Safety Science, 120(December), pp. 527-537. 
Sakinah, Z. V. (2017) 'Aplikasi Health Belief Model dalam Menganalisis Perilaku Penggunaan Kacamata Pelindung', Jurnal Promkes, 5(1), pp. 115-128.

Sim, S. W., Moey, K. S. P. and Tan, N. C. (2014) 'The use of Facemasks to Prevent Respiratory Infection: A Literature Review in the Context of the Health Belief Model', Singapore Medical Journal, 55(3), pp. 160-167.
Suma'mur (2013) Higiene Perusahaan Dan Kesehatan Kerja (Hiperkes). Jakarta: Sagung Seto.

Wright, T. et al. (2019) 'Issue of Compliance with use of Personal Protective Equipment among Wastewater Workers Across the Southeast Region of the United States', International Journal of Environmental Research and Public Health, 16(11), pp. 1-18. 